\title{
The effect of thermal shock on morphological characteristics of blood cells in Siberian sturgeon (Acipenser baerii) triploids
}

\author{
Teresa Wlasow, Dorota Fopp-Bayat \\ Department of Ichthyology, Faculty of Environmental Science and Fisheries, \\ University of Warmia and Mazury in Olsztyn, Poland
}

Received July 26, 2010

Accepted October 26, 2010

\begin{abstract}
The aim of the study was to evaluate the effect of thermal shock on morphotic blood elements in Siberian sturgeon Acipenser baerii triploids. The thermal shock $\left(37^{\circ} \mathrm{C}\right.$ for $\left.2 \mathrm{~min}\right)$ was applied in the $18^{\text {th }}$ min after fertilization. Blood was sampled from parallel cultured ten triploids and ten diploids on day 70 after hatching. Ploidy was assessed with the cytogenetic method and measurements of cellular nuclei. In the blood of triploids, significant dominance of immature red blood cells, erythrocytes with a displaced nucleus, microcytes and erythroplastids were observed. The blood of triploids was also characterized by a reduced number of lymphocytes. The percentage of neutrophil and eosinophil granulocytes was elevated; increased share of neutrophil granulocytes with a 4-, 5- or 6-segmented nucleus and eosinophil granulocytes with a nucleus consisting of three and more segments was observed. Disturbances in the picture of red blood cells can be considered as an expression of intensification of end-stage changes in triploids. The response to these changes in the blood of triploid Siberian sturgeon is an increase in the share of polymorphonuclear PMN, cells counted as microphages. Frequent presence of immature red blood cells in triploid Siberian sturgeon is a process that aims at counterbalancing the loss among these blood cells. It is the first report on morphological changes and proportions among blood cells in triploid Siberian sturgeon.
\end{abstract}

Fish, genome manipulations, polyploidy, disturbances

Current aquaculture of many fish species applies many genome engineering techniques such as triploidization by thermal or pressure shock. The aim of such genome manipulations is production of triploid fish, characterized by faster body weight gains, improved resistance to diseases and weaker aggressiveness, which is of particular importance in intensive fish culture (Fast 1998). Triploid hybdrids obtained via genome engineering, however, do not always present favourable traits. Among triploid hybrids of Siberian sturgeon Acipenser baerii and bester (Huso huso x A. ruthenus), the survival rate was very low (Fopp-Bayat et al. 2007b). A similar undesirable event occurred among hybrids of rainbow trout and salmon trout (Blanc and Maunas 2005). In triploids of the tench Tinca tinca, the number of leukocytes and concentration of protein in blood were decreased (Svobodova et al. 1998), whereas a triploid brook trout was characterized by undesirable changes in both red and white blood cells (Wlasow et al. 2004).

Triploidization as one of the modern genome manipulation methods in aquaculture is most often applied to salmonids and cyprinids. Genome manipulations on sturgeon fishes attract increasing interest because the creation of sturgeon female fish stock is important for the production of caviar. Induced gynogenesis is an example of such genome manipulations carried out on the white sturgeon (Van Eenennaam et al. 1996), sterlet (Fopp-Bayat et al. 2007a) and Siberian sturgeon (Fopp-Bayat 2007). Our study focuses on Siberian sturgeon which was subjected to triploidization (Fopp-Bayat et al. 2007b). The chromosome number in diploid Siberian sturgeon was described as 240 (Fontana 2002) while the triploid Siberian sturgeon possessed about 360 chromosomes in metaphase plates (Fopp-Bayat et al. 2006). Because triploidization is rarely performed on sturgeon

Address for correspondence:

Prof. dr hab. Teresa Wlasow

Department of Ichthyology, Faculty of Environmental Science and Fisheries

University of Warmia and Mazury, Oczapowskiego 5

Phone: +48895234227

10-719 Olsztyn, Poland

E-mail: tewlasow@uwm.edu.p

http://www.vfu.cz/acta-vet/actavet.htm 
fish, it is especially interesting to gain knowledge on changes in the blood of produced sturgeon triploids. The aim of the present study was to analyze characteristics of blood cells of triploid Siberian sturgeon versus the diploid form.

\section{Materials and Methods}

Ten triploids and ten diploids of Siberian sturgeon Acipenser baerii originated from the Wasosze Fish Farm (Poland). Triploid fish were produced by thermal shock $\left(37^{\circ} \mathrm{C}\right.$ for $\left.2 \mathrm{~min}\right)$ in the $18^{\text {th }}$ minute after fertilization (Fopp-Bayat et al. 2007b). Diploids and triploids originated from the same parents of Siberian sturgeon (one female and one male). Ploidy of the fish was confirmed by the cytogenic and cytometric (measurements of cellular nuclei in erythrocytes) methods (Fopp-Bayat et al. 2006). Blood for haemotologic tests was sampled from caudal vessels on day 70 after hatching. In each fixed and dyed preparation, 500 red blood cells and 200 white blood cells were analyzed. The following categories of red blood cells were considered: mature erythrocytes and immature red cells, microcytes (smaller than red blood cells), erythrocytes with a displaced nucleus, erythrocytes with a divided nucleus, erythroplastids (without nuclei). Among white blood cells, the following were analyzed: lymphocytes (forms without processes), excited lymphocytes (with processes), myelocytes, neutrophil (PMN) granulocytes with a rod-shaped nucleus, neutrophil granulocytes with 2 and more segmented nuclei, eosinophil granulocytes with a rod-shaped nucleus, with a nucleus divided into 2, 3 and $>3$ segments. The results were analyzed statistically using Student's $t$-test. The differences were considered significant at $p<0.05$.

\section{Results}

All ten specimens studied from the control group possessed about 240 chromosomes (from 229 to 240 chromosomes in particular analyzed metaphase plates) that was typical chromosome number for normal Acipenser baeri (Fontana 2002). In the sample of triploid fish all ten specimens studied possessed about 360 chromosomes (from 346 to 360) in analyzed metaphase plates. Differences in the erythrocyte nucleus major axis between diploid and triploid fish are shown. Analysis of red blood cells in triploid Siberian sturgeon with a higher ratio of immature cells, erythrocytes with displaced or divided nucleus, microcytes and erythroplastids, compared to diploid individuals are shown in Table 1 and Figs 1, 2. In the white cell profile, there was a significant increase in the neutrophil granulacytes $(\mathrm{PMN})$ possessing 4, 5 and $>5$ nuclear segments and eosinophil granulocytes with a nucleus comprising 3 and $>3$ segments. A lower percentage of lymphocytes were observed in triploids (42\%) than in diploids (68\%) (Table 2, Plate II, Figs 1 and 2).

\section{Discussion}

The results of this study are the first report on morphological changes and proportions among blood cells in triploid Siberian sturgeon. In triploids of shortnose sturgeon

Table 1. Percentage of red blood cells forms in triploid and diploid Siberian sturgeon

\begin{tabular}{lrc}
\hline Forms of red blood cells & $\begin{array}{c}\text { Triploid sturgeon } \\
\text { Mean } \pm \mathrm{SD}\end{array}$ & $\begin{array}{c}\text { Diploid sturgeon } \\
\text { Mean } \pm \mathrm{SD}\end{array}$ \\
\hline Normal mature & $56.56^{*} \pm 8.57$ & $94.18^{*} \pm 2.73$ \\
erythrocytes & $2.36^{*} \pm 1.17$ & $0.59^{*} \pm 0.33$ \\
$\begin{array}{l}\text { Microcytic cells } \\
\text { Erythrocytes }\end{array}$ & $10.37^{*} \pm 3.36$ & $1.12^{*} \pm 0.69$ \\
with displaced nuclei & & \\
$\begin{array}{l}\text { Erythrocytes } \\
\text { with divided nuclei }\end{array}$ & $0.60^{*} \pm 0.60$ & $0.03^{*} \pm 0.09$ \\
$\begin{array}{l}\text { Erythroplastids } \\
\text { Immature red cells }\end{array}$ & $1.04^{*} \pm 0.57$ & $0.35^{*} \pm 0.30$ \\
\hline
\end{tabular}

*Significant differences at $p<0.05$
A. brevirostrum obtained by using pressure shock ('soon after fertilization'), anomalies in red blood cells were likewise more frequent: cells without nuclei (erythroplastids), 'dumbbellshaped' erythrocytes (narrower in the centre), twisted cells and drop-shaped cells or erythrocytes with a divided nucleus (Beyea et al. 2005). Thus, triploid sturgeons demonstrate similar changes. Erythrocytes with a nucleus shifted away from the centre are more often found in triploids of salmonids (Benfey 1999; Wlasow et al. 
Table 2. Comparisons of the percentage of white blood cells forms in triploid and diploid Siberian sturgeon

\begin{tabular}{lccc}
\hline Forms of white blood cells & Triploid sturgeon \\
Mean \pm SD & $\begin{array}{c}\text { Diploid sturgeon } \\
\text { Mean } \pm \text { SD }\end{array}$ & $P$ & $<0.01$ \\
\hline Lymphocytes & $37.70 \pm 17.54$ & $58.30 \pm 9.69$ & $<0.02$ \\
Lymphocytes with cytoplasmic pseudopodia & $4.34 \pm 3.08$ & $10.06 \pm 5.65$ & $\mathrm{~N}$ \\
Myelocytes & $0.90 \pm 0.89$ & $0.64 \pm 0.74$ & $\mathrm{~N}$ \\
Neutrophil granulocytes with rods nuclei & $0.87 \pm 1.59$ & $0.96 \pm 1.03$ & $<0.05$ \\
Neutrophil granulocytes with 2 segments of nuclei & $1.23 \pm 1.22$ & $3.83 \pm 3.39$ & $\mathrm{~N}$ \\
Neutrophil granulocytes with 3 segments of nuclei & $12.15 \pm 5.11$ & $12.55 \pm 6.19$ & $<0.001$ \\
Neutrophil granulocytes with 4 segments of nuclei & $21.11 \pm 6.94$ & $9.14 \pm 4.24$ & $<0.01$ \\
Neutrophil granulocytes with $\geq$ 5 segments of nuclei & $16.44 \pm 12.01$ & $2.33 \pm 4.62$ & $\mathrm{~N}$ \\
Eosinophilic granulocytes with rods nuclei & 0 & $0.06 \pm 0.19$ & $\mathrm{~N}$ \\
Eosinophilic granulocytes with 2 segments of nuclei & $1.44 \pm 0.73$ & $1.31 \pm 1.50$ & $<0.05$ \\
Eosinophilic granulocytes with $\geq 3$ segments of nuclei & $3.82 \pm 3.73$ & $0.82 \pm 0.74$ & $<$ \\
\hline
\end{tabular}

N- Not significantly different at $P<0.05$

2004), including rainbow trout triploids obtained by thermal shock (Johari et al. 2008). An increase in the count of this type of blood cells is observed in different cases of general pathogenic changes and under environmental stress.

A decreased size of erythrocytes in the peripheral blood of fish is a stage in morphological changes in the final phase of a cell's life, during apoptosis (Fijan 2002). It can be supposed that large erythrocytes of triploids are too difficult to be phagocytosed and therefore have to be divided. It is questionable, however, if the shifting of a nucleus in the red blood cell is also such a preparatory step to the end stage in a cell's life. It can be supposed that this process leads to appearance of larger and smaller erythrocytes without nuclei. The increased share of microcytes, erythroplastids and erythrocytes with a displaced or divided nucleus is an expression of intensification of end-of-life changes in these cells in the blood of Siberian sturgeon triploids. Parallel to this, the response to degenerative changes in red blood cells in peripheral blood consists of producing a higher percentage of granulocytes, cells considered as microphages. On the other hand, the evident increase in the share of immature red blood cells in Siberian sturgeon triploids can be considered as a process of compensation of degenerative changes among these cells. White cell profiles in triploid fish have been analyzed less often than erythrocytes and red blood cell (Benfey 1999; Maxime 2008). In the leukocyte profile of the analyzed sturgeon, the percentage of neutrophil granulocytes with a larger number of nuclear segments was significantly higher in triploids than in diploids, analogously to the brook trout (Wlasow et al. 2004). Granulocytes with a segmented nucleus more often occurred in a triploid than a diploid tench (Svobodova et al. 2001). Divisions of nuclei in erythrocytes and granulocytes of triploid fish into smaller fragments can be observed; however, in sturgeon there is no tendecy to divide nuclei of lymphocytes, as has been seen in triploids of trout (W la s ow et al. 2004). In the blood of Siberian sturgeon, lymphocytes are dominant blood cells. Compare $68.4 \%$ in a 70 -day-old sturgeon tested in this study with 68-73.5\% (Palikova et al. 1999) and 66.1 $\pm 12.4 \%$ (Gomulka et al. 2008). A smaller count of blood cells, including white cells, is a characteristic of triploid fish (Benfey 1999), in which depressed counts of white cells responsible for defence mechanisms in fish is a reflection of immunosuppression associated e.g., with stress caused by exposure to toxic factors (Kopp et al. 2010). A significant decrease in the count of lymphocytes under stress in salmonid fish (Benfey and Biron 2000) supports the statement that cells of the defence system in this type of fish are particularly vulnerable. 


\section{Acknowledgement}

The study was supported by the project 08040809 of University of Warmia and Mazury in Olsztyn, Poland.

\section{References}

Benfey TJ 1999: The physiology and behavior of triploid fishes. Rev Fish Sci 7: 39-67

Benfey TJ, Biron M 2000: Acute stress response in triploid rainbow trout Oncorhynchus mykiss and brook trout Salvelinus fontinalis. Aquaculture 184: 167-176

Beyea MM, Benfey TJ, Kieffer JD 2005: Hematology and stress physiology of juvenile diploid and triploid shortnose sturgeon (Acipenser brevirostrum). Fish Physiol Biochem 31: 303-313

Blanc JM, Maunas P 2005: Farming evaluation of the 'brownbow' triploid hybrid (Oncorhynchus mykiss x Salmo trutta). Aquaculture Int 13: 271-281

Fast AW 1998: Aqua farmer information sheet: Triploidy Chinese catfish - Center for Tropical and Subtropical Aquaculture Publication 134: 1-4

Fijan N 2002: Morphogenesis of blood cell lineages in channel catfish. J Fish Biol 60: 999-1014

Fontana F 2002: A cytogenetic approach to the study of taxonomy and evolution in sturgeons. J Appl Ichthyol 18: $226-233$

Fopp-Bayat D, Jankun M, Woznicki P 2006: Chromosome number and erythrocyte nuclei length in triploid Siberian sturgeon Acipenser baeri Brandt. Caryologia 59: 319-321

Fopp-Bayat D 2007: Verification of meiotic gynogenesis in Siberian sturgeon (Acipenser baeri) using microsatellite DNA and cytogenetical markers. J Fish Biol 77: 478-485

Fopp-Bayat D, Kolman R, Woznicki P 2007a: Induction of meiotic gynogenesis in sterlet (Acipenser ruthenus). Aquaculture 264: 54-58

Fopp-Bayat D, Jankun M., Woznicki P, Kolman R 2007b: Viability of diploid and triploid larvae of Siberian sturgeon and bester hybrids. Aquacult Res 38: 1301-1304

Gomulka P, Wlasow T, Velíšek J, Svobodová Z, Chmielinska E 2008: Effects of eugenol and MS 222 anesthesia on Siberian sturgeon Acipenser baerii Brandt. Acta Vet Brno 77: 447- 453

Johari S A, Kalbassi MR, Sourinezhad I, Wlasow T 2008: Observation of red blood cell alterations in triploid rainbow trout (Oncorhynchus mykiss). Acta Sci Pol Piscaria 7: 49-52

Kopp R, Palíková M, Navrátil S, Kubíček Z, Ziková A, Jan Mareš J 2010: Modulation of biochemical and haematological indices of silver carp (Hypophthalmichthys molitrix Val.) exposed to toxic cyanobacterial water bloom. Acta Vet Brno 79: 135-146

Maxime V 2008: The physiology of triploid fish: current knowledge and comparisons with diploid fish. Fish 9: $67-78$

Palikova M, Mares J, Jirasek J 1999: Characteristics of leukocytes and thrombocytes of selected sturgeon species from intensive breeding. Acta Vet Brno 68: 259-264

Svobodova Z, Kolarova J, Flajshans M 1998: The first findings of the differences in complete blood count between diploid and triploid tench, Tinca tinca L. Acta Vet Brno 67: 243-248

Svobodová Z, Flajshans M, Kolárová J, Modrá H, Svoboda M, Vajcová V 2001: Leukocyte profiles of diploid and triploid tench, Tinca tinca L. Aquaculture 198: 159-168

Van Eenennaam AL, Van Eenennaam JP, Medrano JF, Doroshov SI 1996: Rapid verification of meiotic gynogenesis and polyploidy in white sturgeon (Acipenser transmontanus Richardson). Aquaculture 147: 177-189

Wlasow T, Kuzminski H, Woznicki P, Ziomek E 2004: Blood cells alteration in triploid brook trout Salvelinus fontinalis (Mitchill). Acta Vet Brno 73: 115-118 
Plate II

Wlasow T. et al.: The effect of thermal ... pp. 215-218

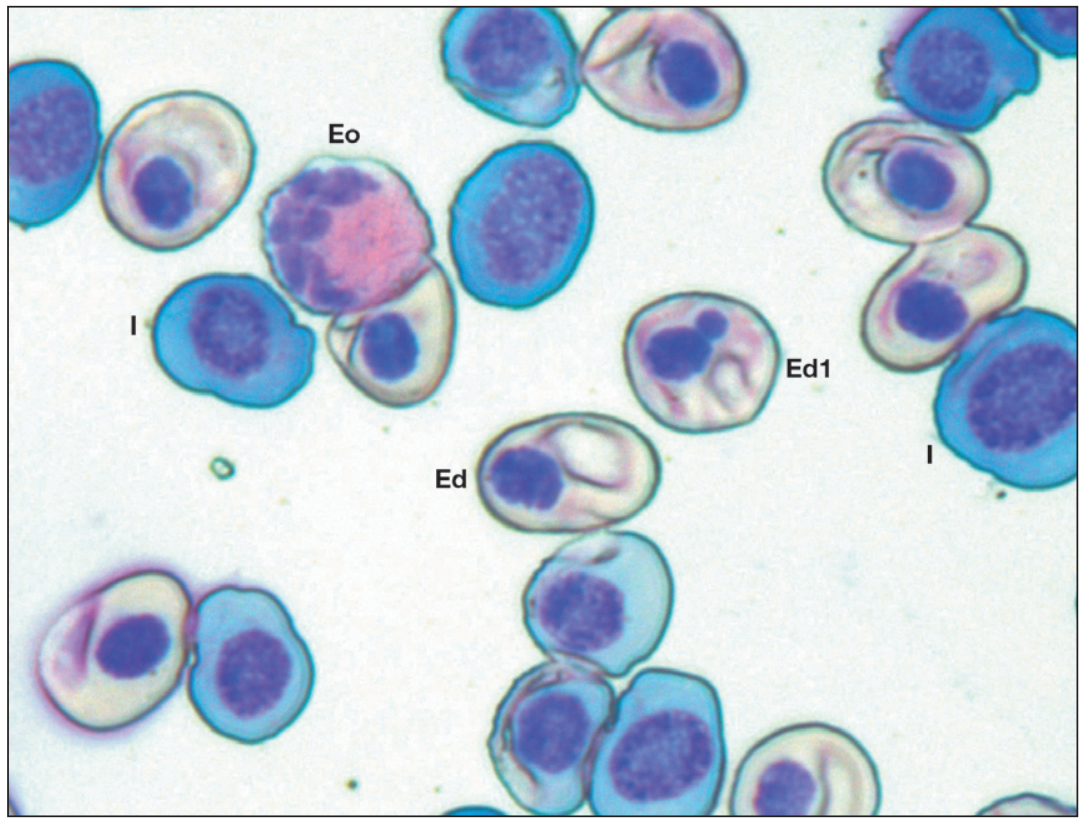

Fig. 1. Peripheral blood of Siberian sturgeon triploid.

Eo - eosinophilic granulocyte, I - immature red cells, Ed - erythrocyte with dislocated nucleus, Ed1 erythrocyte with divided nucleus

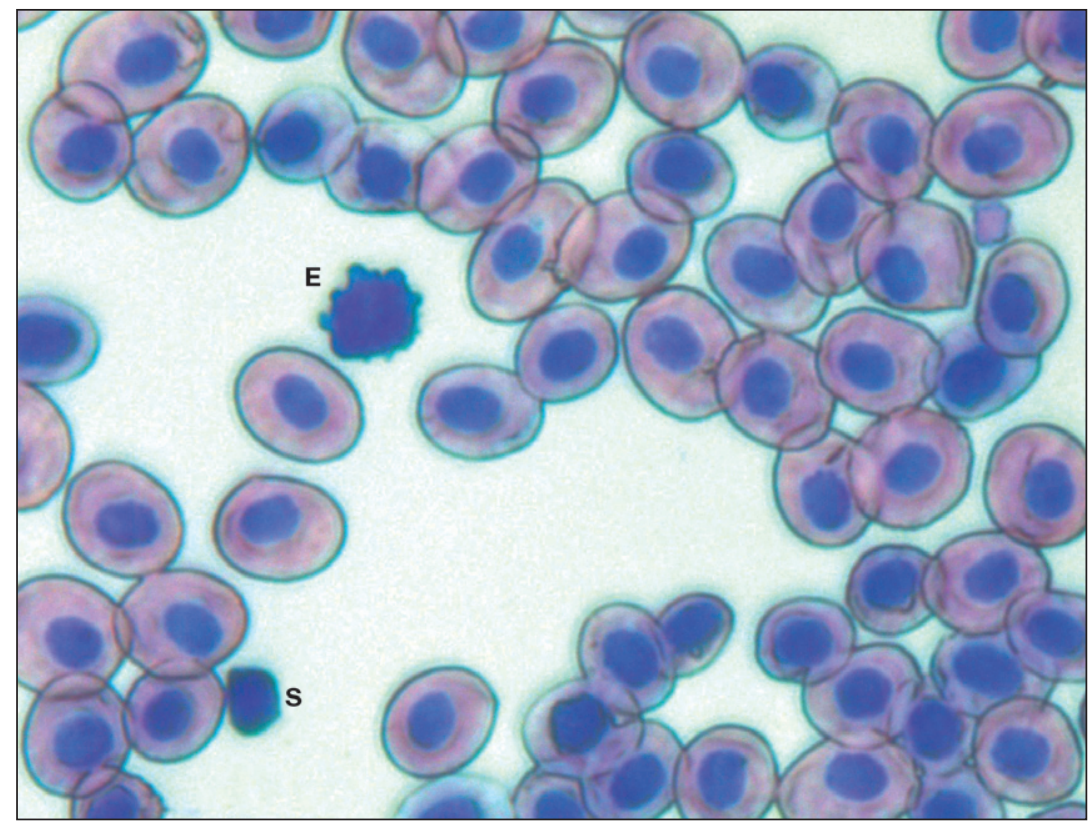

Fig. 2. Peripheral blood of Siberian sturgeon diploid. Lymphocytes: form without processes (small) and excited lymphocyte.

$\mathrm{S}$ - small lymphocyte, E - excited lymphocyte 